\title{
THE EFFECTIVENESS OF GOOGLE CLASSROOM MEDIA IN TEACHING ENGLISH FOR TOURISM AT A TOURISM AND BUSINESS INSTITUTE
}

\author{
Ni Komang Arie Suwastini*, I Made Drati Nalantha, Gede Rasben Dantes \\ Universitas Pendidikan Ganesha, Indonesia \\ (arie.suwastini@undiksha.ac.id)
}

Received: $01^{\text {st }}$ August 2021; Revised: $15^{\text {th }}$ October 2021; Accepted: $27^{\text {th }}$ December 2021

\section{ABSTRACT}

The present study examined the effectiveness of Google Classroom media in teaching English for tourism students at a private Tourism and Business Institute in Bali during mandatory online learning in 2020. The study was qualitative research, implementing the QAIT model for evaluating the effectiveness of Google Classroom in teaching English, involving four lecturers and 42 students. The data were collected through observations of the teaching-learning process in two classes and interviews with the lecturers. The researchers were the primary research instrument, supported by interview guides and an observation checklist. In general, the use of Google Classroom in these English for Tourism classes was only sufficiently effective, with only one lecturer performing well, two lecturers performing sufficiently, and one lecturer performing insufficiently. Obstacles identified among the students were lousy internet connection, lack of device, low motivation, and lack of readiness in using the online learning platform. In conclusion, the implementation of Google Classroom in the observed English Classroom was proven to be only sufficient. This conclusion implies the need for more training for teachers in using Google Classroom to improve the quality, appropriateness, incentive, and timeeffectiveness of the teaching and learning process, especially in online learning.

Key Words: google classroom; online learning; english for tourism; QAIT

\section{ABSTRAK}

Penelitian ini mengamati efektivitas media Google Classroom dalam pengajaran bahasa Inggris untuk mahasiswa pariwisata di Institut Pariwisata dan Bisnis swasta di Bali selama pembelajaran online wajib tahun 2020. Penelitian ini adalah penelitian kualitatif, mengimplementasikan model QAIT untuk mengevaluasi efektivitas Google Classroom di pengajaran bahasa Inggris, yang melibatkan empat dosen dan 42 mahasiswa. Pengumpulan data dilakukan melalui observasi proses belajar mengajar di kedua kelas dan wawancara dengan dosen. Peneliti bertindak sebagai instrumen penelitian utama, didukung oleh pedoman wawancara dan daftar periksa observasi. Secara umum penggunaan Google Classroom pada kelas Bahasa Inggris untuk Pariwisata ini baru cukup efektif, dengan hanya satu dosen yang berprestasi baik, dua dosen berprestasi cukup, dan satu dosen dirasa kurang memadai. Kendala yang ditemukan pada siswa adalah koneksi internet yang buruk, kurangnya perangkat, motivasi yang rendah, dan kurangnya kesiapan dalam menggunakan platform pembelajaran online. Kesimpulannya, penerapan Google Classroom di Kelas Bahasa Inggris yang diamati terbukti hanya cukup. Kesimpulan ini menyiratkan perlunya lebih banyak pelatihan bagi guru dalam menggunakan Google Classroom untuk meningkatkan kualitas, kesesuaian, insentif, dan efektivitas waktu proses belajar mengajar, terutama dalam pembelajaran online.

Kata Kunci: google classroom; pembelajaran daring; english for tourism; QAIT

How to Cite: Suwastini, N. K. A., Nalantha, I. M. D., \& Dantes, G. R. (2021). The Effectiveness of Google Classroom Media in Teaching English for Tourism at a Tourism and Business Institute. IJEE (Indonesian Journal of English Education), 8(2), 259-280. doi:10.15408/ijee.v8i2.21932

\section{* Corresponding author}

IJEE (Indonesian Journal of English Education), 8(2), 2021, 259-280

P-ISSN: 2356-1777, E-ISSN: 2443-0390 | DOI: http://doi.org/10.15408/ijee.v8i2.21932

This is an open access article under CC-BY-SA license (https:/creativecommons.org/licenses/by-sa/4.0/) 


\section{INTRODUCTION}

During the COVID pandemic, everyone must keep their distance from each other to avoid spreading this virus. This obligation is also mandated in Indonesia, as instructed in circular letter number HK.02.01/Menkes/ 199/2020 concerning Communication on Handling Covid-19 (Ministry of Health Indonesia, 2020). However, learning activities must be carried on to maintain the quality of education. Thus, online classes are conducted to replace conventional face-to-face classes. In this setting, learning activities are carried out in the students' and the lecturer's residences without the necessity to meet in a physical classroom, as outlined in the Minister of Education and Culture circular letter No.4 of 2020. This letter states that all academic activities must be conducted online until an undetermined time limit (Minister of Education and Culture Indonesia, 2020), both during the pandemic and whenever necessary. This concept of online learning is made possible by the development of technology, where sophisticated gadgets and various online learning platforms are available (Afifi, 2011; Dantes et al., 2019).

Google Classroom is becoming one of the leading choices for online teaching, with the Ministry of
Education and Culture conducting training on using Google Classroom for teachers. Google creates this teaching platform to help educational institutions in providing education. Google Classroom offers many advantages that make it easy for teachers to educate their students in the teaching and learning process (Phoenix, 2020). This teaching and learning process is inside and outside the classroom because students can learn anywhere and anytime by accessing Google Classroom online. Further, this platform becomes a learning management system that can provide students with teaching materials and test facilities (Nicholson, 2020).

Google Classroom is deemed as one of the platforms that are the easiest to use and is argued to offer many benefits, such as accessibility, flexibility, and adaptability in the teaching and learning process (Alim et al., 2019; Beaumont, 2018; Guzman et al., 2017; Heggart \& Yoo, 2018; Iftakhar, 2016; Sukmawati \& Nensia, 2019; Syakur et al., 2020). However, many studies have argued that Google Classroom also challenges teachers and students across levels. School children were found to have problems with the connection, insufficient readiness to use the online learning platform, and lack of preparedness to autonomous learning generally required in online learning 
(Abidin \& Saputro, 2020; Bhat et al., 2018; Puspitasari et al., 2021; Suhroh \& Cahyono, 2020; Zakaria, 2021).

Considering the emergency and mandatory nature of online learning, evaluation needs to be conducted to determine how effective the implementation of online learning using Google Classroom is, especially in the first months of the pandemic. As teachers and students are forced to adopt online learning methods and pick Google Classroom as the platform, the teachers' technological competence may affect the quality of teaching and learning in conventional face-to-face teaching and online learning. Thus, there is a possibility that this mandatory yet sudden transfer to online learning and the use of Google Classroom may need improvements. Hassan et al. (2020) and Puspitasari et al. (2021) argue that teachers and students found the implementation of Google Classroom during the mandatory online learning at the beginning of the COVID-19 pandemic has posed considerable challenges due to unfamiliarity with the learning management system and technical challenges such as limited internet access and unavailability of digital devices to access the online platform.

Preliminary observation in a tourism and business institute in Bali also indicated that the same problems were experienced by the lecturers and the students, especially during the emergency online teaching mandated since March 2020. Many meetings were canceled during the switch, with lecturers trying to find ways to keep the knowledge transfer going. The next term of the mandatory online teaching that started in the second half of the year sometimes gave lecturers and students more ready. Many lecturers also opted for the same learning management system to conduct their instructions in higher education, including lecturers in the tourism and business institute previously observed. Considering the many challenges teachers and students face in the implementation of Google Classroom, the present study aimed to evaluate the implementation of Google Classroom in an EFL class in a tourism and business institute in Bali using Slavin's (2017) QAIT model.

Slavin (2017) proposes a QAIT model in seeing the effectiveness of learning through four inter-related elements of instruction: the Quality, the Appropriate level, the Incentive, and Time management. Quality of Instruction concerns how educators convey information systems to enable the students to achieve the learning goals. An appropriate level of instruction deals with whether an 
instruction is suitable for the student's level of readiness, as reflected by the students' responses during the instruction and their accomplishment of the assignments. From the aspect of Incentive, the learning process is evaluated concerning how educators motivate students to be enthusiastically engaged during the learning process. The aspect of Time in Slavin's model evaluate whether or not the teachinglearning process is conducted in effective time management: whether or not the learning objectives are achieved within the allocated time, with the proper arrangement as how much time is used for apperception and preactivity, whilst-activity, and postactivity as well as for assessment.

The present study implemented Slavin's QAIT model to follow the preliminary observation of using Google Classroom in online learning in Bali's tourism and business institute. It was essential to conduct this research because there have been many indications of challenges faced by teachers in using Google Classroom as the platform recommended by the ministry to be used during the mandatory online learning due to the COVID-19 pandemic. Puspitasari et al. (2021) found that older teachers had a hard time adapting to Google Classroom at the beginning of the pandemic. Hassan et al. (2020),
Octaberlina and Muslimin (2020), and Zulkefli et al. (2020) found that students found it challenging to use Google Classroom because the students that they observed did not have a reliable internet connection. They found that the unstable internet connection demotivated the students to study. Atmojo and Nugroho (2020) found that Google Classroom cannot motivate the students to participate in the discussion tabs. Meanwhile, students had difficulty comprehending the learning material shared through Google Classroom because they were not explained in detail (Agung et al., 2020; Atmojo and Nugroho, 2020).

Moreover, the preliminary observation indicated that the lecturers experienced difficulties implementing Google Classroom. The teachinglearning process should be investigated further to provide a deeper understanding of the process and the challenges experienced by the lecturers in the classroom under investigation. This study's result would become a direct recommendation for the institute where the study was conducted. However, in the broader contexts, the results of this study can also serve as reflections for teachers and lecturers who implement Google Classroom. The results can build recommendations for teachers and educators about problems in implementing Google Classroom and 
online learning in general, which may be taken to stakeholders as considerations in making further policies related to online learning and implementations of specific learning management systems.

\section{METHODS}

\section{Research design}

The research method used in this study was a descriptive qualitative method through an in-depth online interview which follows Miles et al.'s (2014) model of qualitative data analysis. The main instrument for the data collection was the researcher, who assisted with observation sheets and interview guides. The rubric of QAIT evaluation is displayed in Table 1, while the interview guides are displayed in Table 2 and Table 3.

Table 1. The rubric of QAIT evaluation for evaluating the Teaching-learning process

\begin{tabular}{|c|c|c|c|c|}
\hline $\begin{array}{l}\text { Aspects of } \\
\text { Evaluation }\end{array}$ & Very Good & Good & Sufficient & Insufficient \\
\hline $\begin{array}{l}\text { Quality of } \\
\text { instruction }\end{array}$ & $\begin{array}{l}\text { All students have } \\
\text { satisfactory learning } \\
\text { outcomes in } \\
\text { accordance with the } \\
\text { learning objectives. }\end{array}$ & $\begin{array}{lr}\text { Most } & \text { students have } \\
\text { good } & \text { learning } \\
\text { outcomes } & \text { following } \\
\text { the } & \text { learning } \\
\text { objectives. }\end{array}$ & $\begin{array}{l}\text { Some students have } \\
\text { good learning } \\
\text { outcomes in } \\
\text { accordance with the } \\
\text { learning objectives. }\end{array}$ & $\begin{array}{l}\text { Most students have } \\
\text { learning outcomes } \\
\text { that are incompatible } \\
\text { with learning } \\
\text { objectives. }\end{array}$ \\
\hline $\begin{array}{l}\text { Appropriate } \\
\text { level of } \\
\text { instruction }\end{array}$ & $\begin{array}{l}\text { All students } \\
\text { understood the } \\
\text { instructions quickly; } \\
\text { all students did their } \\
\text { assignments } \\
\text { according to the } \\
\text { instructions given by } \\
\text { the lecturer. }\end{array}$ & $\begin{array}{l}\text { Most students } \\
\text { understood the } \\
\text { instructions well; } \\
\text { most students did } \\
\text { their assignments } \\
\text { correctly according } \\
\text { to the instructions } \\
\text { given by the lecturer. }\end{array}$ & $\begin{array}{l}\text { Some students } \\
\text { understood the } \\
\text { instructions, but } \\
\text { most of them did not } \\
\text { fully understand } \\
\text { them; some did the } \\
\text { assignments } \\
\text { correctly according } \\
\text { to the instruction } \\
\text { given by the lecturer. }\end{array}$ & $\begin{array}{l}\text { Most of the students } \\
\text { were confused about } \\
\text { the instructions; } \\
\text { students did not do } \\
\text { the assignments or } \\
\text { did them incorrectly } \\
\text { without following } \\
\text { the instructions } \\
\text { given by the lecturer. }\end{array}$ \\
\hline Incentive & $\begin{array}{l}\text { All students are } \\
\text { active in } \\
\text { commenting and } \\
\text { sharing opinions on } \\
\text { class discussions on } \\
\text { the stream or } \\
\text { classwork tab. }\end{array}$ & $\begin{array}{l}\text { Most students are } \\
\text { active in } \\
\text { commenting and } \\
\text { sharing opinions on } \\
\text { class discussions on } \\
\text { the stream or } \\
\text { classwork tab. }\end{array}$ & $\begin{array}{l}\text { Some students are } \\
\text { active in } \\
\text { commenting and } \\
\text { sharing opinions on } \\
\text { class discussions on } \\
\text { the stream or } \\
\text { classwork tab. }\end{array}$ & $\begin{array}{l}\text { No students actively } \\
\text { comment and share } \\
\text { opinions on class } \\
\text { discussions in the } \\
\text { classwork stream or } \\
\text { tab. }\end{array}$ \\
\hline \multirow[t]{2}{*}{ Time } & \multirow[t]{2}{*}{$\begin{array}{l}\text { - Lessons finish on } \\
\text { time } \\
\text { - All students } \\
\text { submit } \\
\text { assignment the } \\
\end{array}$} & \multirow[t]{2}{*}{$\begin{array}{l}\text { - Lessons finish on } \\
\text { time } \\
\text { - Most students } \\
\text { submit the } \\
\text { assignment on }\end{array}$} & $\begin{array}{l}\text { - Lessons finish late } \\
\text { - Some students are } \\
\text { late in submitting } \\
\text { assignments }\end{array}$ & $\begin{array}{l}\text { - Lessons finish late } \\
\text { - Most students are } \\
\text { late in submitting } \\
\text { assignments }\end{array}$ \\
\hline & & & learning & learning \\
\hline
\end{tabular}




\begin{tabular}{|c|c|c|c|c|}
\hline $\begin{array}{l}\text { Aspects of } \\
\text { Evaluation }\end{array}$ & Very Good & Good & Sufficient & Insufficient \\
\hline & $\begin{array}{l}\text { time } \\
\text { - All learning } \\
\text { objectives are } \\
\text { achieved within } \\
\text { the time allocated }\end{array}$ & $\begin{array}{l}\text { time } \\
\text { - Most learning } \\
\text { objectives are } \\
\text { achieved within } \\
\text { the time allocated }\end{array}$ & $\begin{array}{lr}\text { objectives } & \text { are } \\
\text { achieved within } \\
\text { the time allocated }\end{array}$ & $\begin{array}{l}\text { objectives are not } \\
\text { achieved within } \\
\text { the time allocated. }\end{array}$ \\
\hline
\end{tabular}

Table 2. Interview Guide for the Lecturers

\begin{tabular}{ll}
\hline Category & Definition \\
\hline Quality of & The quality of instruction refers \\
instruction & to a series of activities carried \\
& out during teaching and \\
& learning activities.
\end{tabular}

Appropriate The way teachers provide the level of appropriate level of teaching instruction for teaching diverse students.

Incentive The way of teachers motivates their students

Time

\section{Question}

1. How do you teach the material to students in Google Classroom?

2. What do you feel about Google Classroom as your new teaching and learning media?

3. How do you inform the assignments to students?

4. How do you believe your instruction is appropriate for your students?

5. How do you motivate your students?

6. How do you make sure students are interested in the lesson?

7. How do you manage the time using Google Classroom?

8. Do you think this platform is efficient and useful? Why?

\section{Table 3. Interview Guides for the Students}

\begin{tabular}{ll}
\hline Category & Definition \\
\hline $\begin{array}{l}\text { Quality of } \\
\text { instruction }\end{array}$ & $\begin{array}{l}\text { The quality of instruction refers } \\
\text { to a series of activities carried } \\
\text { out during teaching and } \\
\text { learning activities. }\end{array}$ \\
$\begin{array}{ll}\text { Appropriate } \\
\text { level of } \\
\text { instruction }\end{array}$ & $\begin{array}{l}\text { The way teachers provide the } \\
\text { appropriate level of teaching } \\
\text { for teaching diverse students. }\end{array}$
\end{tabular}

Incentive

The way of teachers motivates their students.

Time

The efficiency of the time used for teaching and learning
Question

1. Do you understand the material in Google Classroom?

2. What do you feel about Google Classroom as teaching and learning media?

3. How does the lecturer inform the assignments to students?

4. Do you like the teaching-learning process conducted through Google Classroom by the lecturers?

5. Does Google Classroom motivate you to study better?

6. Is the lesson through Google Classroom interesting for you?

7. How do you manage the time using Google Classroom?

8. Do you think this platform is efficient and useful? Why? 
The rubric above was used as guidelines to observe the teachinglearning process as the teacher's and the student's activities were observed in each of the meetings.

\section{Research Site and Participants}

The subjects of this research were four lecturers of English in a tourism and business institute in Bali in the first semester of the Academic Year 2020/2021. The four lecturers taught two English Classes. The first class had twenty-two students, and the second class had twenty students. Lecturer 1 and Lecturer 2 were in team-teaching in the first class, while Lecturer 3 and 4 were in team-teaching in the second class. In these team-teachings, the pair taught the class simultaneously and shared the same syllabus, but they designed their instructions respectively. Forty-two students taught by the four lecturers in the two classes observed in this study were also enrolled as secondary research subjects for confirming the results of interviews and observations conducted with the teachers and the learning process. The objects of the study were the quality, appropriateness, incentive, and time management of the online classes conducted by the research subjects, following Slavin's QAIT Model (2017).

\section{Data Collection and Analysis}

The data collection methods employed in this study were observations and semi-structured interviews.

The observations were conducted on the online learning through Google Classroom and Google Meet as the online, face-to-face meeting. The observations were conducted in five meetings of each of the lecturers' classes. Each of the classrooms was observed five times, making 20 observations altogether. The learning process observed included the recordings of the Google Meets, sharing materials, discussions, sending assignments, doing examinations, grading assignments, giving feedback, and conducting exams. The interviews were conducted using online platforms such as WhatsApp chats, WhatsApp video calls or voice calls, and regular telephone calls with the lecturers and the students.

During the step of data condensation, the data collected were then classified into the four elements of Slavin's QAIT model. This step was conducted while continuously ensuring that all the data were collected and tabulated. After the tabulation was completed, the analysis was continued with categorizing the lecturers' instructions following a set of 
evaluation blueprints adapted from Slavin's QAIT Model. All of the steps in the data collection, data condensation, and data display were conducted interactively to ensure that the conclusion drawn from the process was trustworthy.

\section{FINDINGS AND DISCUSSION}

\section{Findings}

Table 4 displays the result of the observations conducted during the teaching and learning activities in English in tourism students at the International Tourism and Business Institute. The observations were conducted in 2 classes. Two lecturers taught each class in a team-teaching model, where each lecturer designed their contents for their respective Google Classroom. The study observed the teaching-learning process as recorded through Google Meet, the content, and the discussion activities in the Google Classroom. In this case, objects of the observations are the instructions designed by the lecturers, the teaching-learning process conducted by the lecturers, and the activities conducted by the students during the meets and in the online discussion.
Table 4. Observation Result

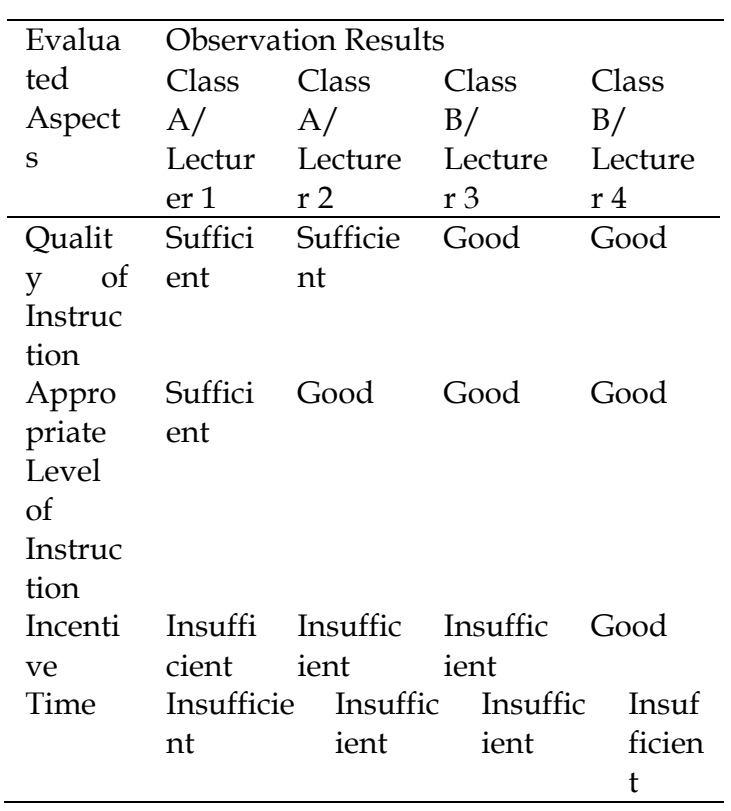

Regarding the quality of instruction, two lecturers conducted their instructions sufficiently while the other two lecturers' instructions were good. Regarding the appropriateness of the instruction level, one lecturer performed sufficiently, while the other three performed well. The incentive of instructions conducted by three lecturers was insufficient, but one lecturer managed to conduct good instruction. However, all four lecturers involved in this study reflected poor time management in terms of time management. In other words, the instruction conducted by Lecturer 1 was sufficient in terms of quality and appropriate level of instruction but insufficient in terms of incentive and 
time management. The instruction conducted by Lecturer 2 was sufficient in terms of quality, good in terms of the appropriate level, but insufficient in terms of incentive and time management. The instruction conducted by Lecturer 3 was good in terms of quality and appropriate level of instructions but insufficient in terms of incentive and time management. The instruction conducted by Lecturer 4 was good in terms of quality of instruction, the appropriate level of instruction, and incentive but insufficient in terms of time management. The overall instruction conducted by Lecturer 1 was insufficient, Lecturer 2 was sufficient, Lecturer 3 was sufficient, and Lecturer 4 was good. In general, the instructions conducted in the beginner classes of the institute under investigation were sufficient.

\section{Discussion}

\section{Quality of Instruction}

From Table 4, it can be observed that the quality of instruction conducted by the four lecturers in the tourism and business institute observed in this study was between sufficient and good. Lecturer 1 and Lecturer 2 conducted sufficient quality of instruction, while Lecturer 3 and Lecturer 4 conducted good quality of instruction.
Lecturer 1 designed the meetings in the Google Classroom with the lesson's topic, gave videos that explained the teaching material and assignments as a form of assessment. The face-to-face meetings usually lasted quite briefly, with the lecturer checking the students' presence and giving assignments, which the students did independently. This lecturer provided the instructions for the assignments on the Classwork tab. The learning goals of the classes taught by the Lecturer 1 was sufficient, with most students did not submit the assignments. Interviews with the students revealed that they did not submit the assignment because they could not do it since they did not understand how to do it. Lecturer 2 had the same instruction pattern, but this lecturer provided more alternative learning sources, such as e-books, PDF files, and videos. This lecturer also provided longer explanations of the topic and the task in face-to-face meetings, with asynchronous discussion opened in the comment section. However, the comment sections did not show any questions from the students. In general, most students did not achieve the learning objectives, despite the richer learning sources provided by the lecturer. Interviews with the students revealed that most students did not read the e-books and the PDF files provided by the lecturer. 
Lecturer 3 and Lecturer 4 designed their instruction more completely. In addition to learning sources in e-books and PDF files, they also provided related educational videos from YouTube and other websites. During the synchronous face-to-face online meetings, while recording the students' presence and giving learning materials, they also explained the teaching material instead of only giving them the materials and asking them to read independently. They provided clear instructions on how to do the assignments. Another significant difference that they did differently from Lecturer 1 and Lecturer 2 was that they invited students to ask questions in the comment sections. They took time to answer the students' questions. Interviews with Lecturer 3 and Lecturer 4 revealed that they tried to conduct process assessment through the asynchronous discussion to assess whether the students understood the learning material. They admitted that making their students ask questions or respond to the lecturers' questions was challenging. Observations on the comment section revealed that students mostly ask about technical aspects like submitting the assignment, in what format, and whether the deadline was fixed. The instructions conducted by Lecturer 3 and Lecturer 4 seemed to yield better quality of instruction since most of their students achieved the learning goals with good outcomes.

The instructions conducted by Lecturer 1 and Lecturer 2 relied on taskbased learning that can force students to practice learning autonomy, especially among adult learners. However, the students might have been unready with high learning autonomy as they were in their first year in the university. Thus, the lack of interaction between the lecturers and the students seemed to affect the students negatively. When they did not understand the instruction, they did not ask. When they were provided with more learning sources, they did not access them. Fauzan and Arifin (2019) also found that the teaching and learning process weaknesses using Google Classroom can be caused by students' reluctance to read. As the students were passive, Lecturer 1 and Lecturer 2 did not adjust to the students' learning profiles. They acted as learning facilitators who directed students to carry out certain activities without step-by-step assistance, leading to students' failure to do the assignment and negatively affecting their learning outcomes. Fauzan \& Arifin (2019) also found the same phenomenon where failure in understanding the teacher's instructions for the assignments resulted in the students' failure to do and submit their assignments. 
Instructions provided by the lecturers need to be clear and complete to allow students to learn more effectively (Syakur et al., 2020). Furthermore, the teacher needs to assist in the learning process instead of simply relying on assignment completion as the only assessment. Ersani et al. (2021) argue the importance of providing scaffolding for students in an online setting because students have different readiness that may affect how they progress during the learning process and its outcome.

The instructions conducted by Lecturer 3 and Lecturer 4 were of better quality when compared to those conducted by Lecturer 1 and 2 because of the relatively productive asynchronous discussion they conducted. The study conducted by Muslimah (2018) confirms these findings. She observed that productive discussion in Google Classroom could lead to better learning quality. The discussions may not be limited to the learning contents and technical aspects since many students were not familiar with Google Classroom and how to submit assignments via online platforms. Although this may not be related directly to the quality of instruction conducted by Lecturer 3 and Lecturer 4, the teachers' explanation of these technicalities facilitated the students submitting their assignments, albeit some tardiness. This finding is similar to the findings conducted by Azhar and Iqbal (2018), Fauzan and Arifin (2019), and Megawati and Astutik (2019). They revealed that the mastery of Google Classroom features affected the quality of the learning process and the learning outcomes. Similarly, Shaharanee et al. (2016) argue that Google Classroom should be used as a tool for active learning. The success of the instruction depends on how the teachers guide their students; Both in terms of learning content and how to navigate the online system.

\section{Appropriate Level of Instruction}

Table 4 displays that the instructions designed by the lecturers in the tourism and business observed in this study were generally good. Lecturer 2, Lecturer 3, and Lecturer 4 designed and conducted their instructions well, while Lecturer 1 designed and conducted sufficient instruction.

The instruction designed and conducted by Lecturer 1 seemed to be confusing for most students. Some students did understand the instruction and submitted their assignment, but most of them admitted that they were confused about the instructions given by Lecturer 1 . As described previously, students in the class taught by Lecturer 1 rarely submitted their assignments. Interview with the students revealed 
that most students did not do the assignment because they did not understand how to do it. Observations on the instructions of the assignments provided by Lecturer 1 revealed that the instructions tended to belong with unnecessary notes that confused the students. Besides the interview with Lecturer 1, it was revealed that the lecturer tried to provide instructions with emphasis that if they did not understand the material, they should watch the video again and again until they understood it. Lecturer 1 admitted that the long instructions were provided to help the students understand how to do the assignment. As observed in the Google Classroom comment section, Lecturer 1 did not provide asynchronous discussions.

Unlike Lecturer 1 , the other three lecturers provided asynchronous discussion that allowed the students to ask questions or comments. Interview with the students revealed that the productive comment section helped them understand the teaching material and the assignments' instructions. Thus, more students taught by Lecturer 2, Lecturer 3, and Lecturer 4 submitted their assignments. However, there was a difference in productivity between the asynchronous discussions held by these three teachers. The comment sections in the class taught by Lecturer 2 were not as active as those taught by Lecturer 3 and Lecturer 4.

Nevertheless, the students were equally confident in doing the assignments. Interview with the students taught by Lecturer 2 revealed that they did not ask many questions because they were reluctant. Besides, they also admitted that the instructions to do the assignments were straightforward to follow them well. Observations on the instructions for doing the assignments provided by the three lecturers revealed that they provided short and simple instructions that were easy to understand.

There are two important points to highlight considering the Appropriateness of the instructions level conducted by the four lecturers observed in this study. The first one is the length and clarity of the instructions for the assignments. Observations on the instructions for doing assignments and the interview with the students revealed that short and simple instructions provided by Lecturer 2, Lecturer 3, and Lecturer 4 were more appropriate for the students than the long instructions provided by Lecturer 1. The relevance of shorter and simpler instructions among these students might be related to the fact that they were first-year students who may come to the institute with varying degrees of 
English competence. Thus, shorter and simpler instructions would be more uncomplicated for them to comprehend. The same result was found by Alim et al. (2019), who explored the effectiveness of Google Classroom as an instructional medium and revealed that short and simple instructions were more effective in Google Classroom because they can prevent confusion.

The second point is that the use of the Stream Tab contributed positively to the student's comprehension of the material and the instructions for doing the assignments. Using videos as learning sources in EFL classrooms has been argued to benefit students' language skills, vocabulary, motivations, pronunciation, grammar, and 21st-century skills (Ariantini et al., 2021; Listiani et al., 2021; Puspawati et al. 2021; Wang \& Chen, 2019). Nevertheless, the present study revealed that students still needed guidance during the learning process to prevent them from being stuck and feeling lost. More straightforward and shorter instructions for the assignments can be understood by more competent students and their less-ready friends (Dwiyanti \& Suwastini, 2021; Suwastini et al., 2021). Besides, the discussions in the comment sections can also act as scaffolding to provide additional explanations for students who need more guidance (Ersani et al., 2021).

Beaumont (2018) states that the Google Classroom could store data from the material taught in the Google Classroom so students can quickly return to previous material without needing to ask their friends or educators again. Students can also learn the material from data to remember and re-learn the material taught before. However, the response from the students can be taken as a need for reflection. Despite the usability of Google Classroom for online learning, teachers should avoid using it to store the material and expect them to learn from the material pile. Teachers should not make one-size-fits-all material because students have different learning profiles, readiness, and interests (Ersani et al., 2021; Suwastini et al., 2021). The material stored in the platform should suit the learning theme and facilitate students' learning.

\section{Incentive}

Motivation is essential to students' learning process. In Slavin's QAIT model, the incentive aspect relates to how the instruction designed and conducted by the lecturer can motivate the students to participate in the learning activities and get the best benefits from the learning process. Table 4 shows that on the instruction 
conducted by the four lecturers, the average quality of the instruction was borderline insufficient and sufficient. Three of the four lecturers conducted insufficient instructions, but the instruction conducted by Lecturer 4 was good.

Lecturer 1 was the lecturer whose instruction did not have comment sections. That means there was no interaction between the lecturer and the students after the lecturer was done doing the presence checking and introducing the topics of the meetings on the online, face-to-face meetings. Observation on the instructions conducted by Lecturer 1 revealed that the interaction was limited to the lecturer getting to know if the students were present or absent and, if they were not present, for what reason. Although the interaction seemed to be minimum, Lecturer 1 checked that the students' presence was apparently enough to invite some participation from the students, albeit very few. Lecturer 2 and Lecturer 3 opened comment sections. However, the students in the class taught by Lecturer 2 did not use the opportunity. The comment sections of the classes conducted by Lecturer 2 were not productive. Thus, the interaction in the instructions conducted by Lecturer 2 was more or less similar to those conducted by Lecturer 1 . The students taught by
Lecturer 3 showed more participation than in the learning process conducted by Lecturer 1 and Lecturer 2. However, there was a significant decline in students' participation in the later meetings conducted by Lecturer 3 . Interview with Lecturer 3 revealed that not all students' questions were given feedback, and the students whose comments were not given feedback tended to stop posting comments or asking questions on the comment sections. Interview with the students revealed that they felt it was no use to participate in the comment section anymore because the lecturer did not give feedback. It resulted in the low average of participation in the instructions conducted by Lecturer 3 .

Unlike the other three lecturers, Lecturer 4 conducted instructions that inspired good participation. Lecturer 4 conducted the face-to-face online meetings longer than the average of the three other lecturers. Lecturer 4 took time to answer students' questions during the synchronous meetings. Furthermore, observations on the comment sections and stream tab revealed that most students actively commented and shared opinions about the lecturer's questions. Interviews with Lecturer 4 revealed that the lecturer tried to answer every question the students asked and gave feedback on the students' comments. Interviews 
with the students in this class revealed that they felt motivated to answer questions and comment because they got feedback and reinforcements. The interactions between the lecturer and the students seemed to boost the students' motivations to participate in the learning process, resulting in a good level of incentive.

Thus, the dismissal of the comment section featured in Google Classroom by Lecturer 1 limited the students' participation. The students' reluctance to participate in the comment sections in the instruction conducted by Lecturer 2 reflected the low effort of the lecturer to motivate the students to participate. The lecturer could initiate the discussions by posting specific questions for the students to answer. Sudarsana et al. (2019) found that effective use of the comments section can boost students' participation. The lecturer can also use the comment sections to post a collaborative project that allows students to communicate with their peers through the comments section and coursework tabs. Heggart and Yoo (2018) found that the comments section motivates the students to interact with their peers and build collaborations. The lack of participation among the students in the class taught by Lecturer 3 was similar to the findings from Shaharanee et al. (2016). Students enjoyed interacting with the teachers in their study but not with their peers using Google Classroom. Thus, when Lecturer 3 did not respond to each of the students' comments and questions, they just went inactive instead of commenting on their friends' opinions.

\section{Time}

Table 4 displays that all four lecturers conducted insufficient time management. There were four general problems in the teachers' time management: the inability of the lecturers to finish the material within the time allocation for each meeting, the prolonged response-time to teachers' questions or in giving comments, the students' tardiness in submitting their assignment, and the teachers' difficulties in managing their time to provide feedback and to respond to the students' questions or comments.

In general, all four lecturers could not finish their teaching material within the allocated time. They admitted that they found it difficult to assess whether their students could follow the instructions and comprehend the material adequately because they could not see their expressions. While Google Meet promises face-to-face online interaction, not every student turned on their videos, nor could the screen display all of the students' screens simultaneously. It was very different 
from the immediate assessment of the students' facial expressions and gestures to support a quick process assessment that can help the lecturers decide how to proceed with the instructions. Observations on the instruction conducted by Lecturer 1 revealed that Lecturer 1 provided very few explanations synchronously without asynchronous discussions as follow-ups. Lecturer 2 provided longer explanations and asynchronous discussion, yet the students' reluctance to comment on the stream tab contributed to the lecturer's inability to assess the students' comprehension. Lecturers 3 and 4 had a clearer idea about the students' comprehension only after prolonged, time-consuming discussions.

Lecturer 1 did not have discussion sessions, and the instructions on the assignments were considered confusing by the students. Thus, most students taught by Lecturer 1 did not submit their assignments on time. Interviews with the students admitted that they did not submit their assignments on time because they were confused about the instructions provided by Lecturer 1 . Furthermore, the Appropriateness of instructions conducted by Lecturer 1 was only sufficient. Besides, Lecturer 1 did not use the comment feature. The combination of the instruction's low Appropriateness and the unavailability of asynchronous discussions might have affected the students' prolonged tardiness in submitting their assignments.

The same students were taught by Lecturer 2. Most of them were also tardy in submitting their assignments and responding to the teacher's comments or questions. Unlike Lecturer 1, Lecturer 2 used the comment feature on the Google Classroom, yet hardly any students posted comments or questions. Interview with the students revealed that their late submission was due to the time-consuming nature of the assignments. When viewed from the evaluation of the level appropriateness of the instruction's level conducted by Lecturer 2, the level was good. That means the instructions were appropriate for the student's level and readiness. When questions about this tardiness were brought up, students admitted that they were late because it took them long to finish. Considering that the instruction was appropriate, the students' tardiness might have resulted from their inability to manage their time well.

The students taught by Lecturer 3 were also mostly late in submitting their assignments, despite the excellent quality and level of instruction appropriateness achieved by Lecturer 3 . Observation showed that students 
posed questions on the comment section, yet many were left without the lecturer's responses. As mentioned before, an interview with Lecturer 3 revealed that the lecturer did not reply to all students' questions because of time limitations. Interview with the students taught by Lecturer 3 revealed that they were late submitting assignments because they could not finish the assignments on time. In this case, in the instruction conducted by Lecturer 3, both lecturer and the students had a problem with their time management.

Lecturer 4 had almost all of the students' questions and comments attended to, which may have contributed to the excellent quality, Appropriateness, and incentive from the instructions conducted by Lecturer 4. Nevertheless, observations on the time of the feedback given showed some tardiness. Perhaps, it was because of the many questions and comments the lecturer had to respond to. Interview with Lecturer 4 revealed that the lecturer felt overwhelmed with the many comments that needed feedback. It was stated that the lecturer tried to respond to all of the questions and give feedback to all students' comments and assignments. However, it took so much time to attend them all. Interviews with the students revealed that they did not submit the assignments on time because they were waiting for feedback from the lecturer. Thus, while the students were waiting for feedback, they delayed their submission, causing tardiness in the general submissions. Hence, the instructions conducted by Lecturer 4 were quite similar to that of Lecturer 3 in terms of time management: both the students and the lecturer had problems with time management.

Unlike the case with the results of Muslimah's (2018) study where time management in Google Classroom learning was very effective, the research results in the current study showed that the timing was less effective. The difference in this result was found because the educators in the Muslimah's study applied the Google Classroom more optimally than the teachers in the current study. It means improvement is needed to get better time management in using Google Classroom in the future. Bhat et al. (2018) also found that some students did not submit their assignments on time on Google Classroom because they thought they could submit them beyond the deadline. The teacher would still accept it as they usually do in the case of manual submissions. Besides, lecturers in this study admitted that they did not know if the students told the truth about their problems in submitting their assignments or not. 
This point becomes the lecturers' problem in assessing their work.

Moreover, the instructions of the third and four lecturers here were better than the first and second lecturers, which were compared from the number of submission counts on the classwork tab on Google Classroom. Additionally, to tackle the overwhelming need to give students feedback, teachers can acknowledge students' comments on each other's work as feedback. Another alternative is to post general feedback at the end of the meeting and encourage the students to reflect on their progress in learning. General feedback can improve students' learning autonomy since they have to identify their participation in the classroom. It is more practical for the teachers, as suggested by Heggart and Yoo (2018).

\section{CONCLUSIONS AND SUGGESTION}

Based on the result of this study and the discussion, it can be concluded that using Google Classroom media in teaching English for tourism students is not effective. It is proven by the discussion of this study based on the result of interviews and observations. The researcher found that the lecturer had not yet fully adapted to this teaching media and had not found the right teaching strategy for this media.
This problem emerges because this is the first time lecturers and tourism students have used this media and have not fully adapted to this. The slow response of students makes lecturers assume that students are less interested in using Google Classroom, which makes lecturers want to use other media which are more attractive.

Furthermore, the analysis on the learning effectiveness of using Google Classroom for teaching based on four elements of the QAIT model proposed by Slavin (2017) showed that this media is less optimal in teaching English. In addition, lecturers face many problems, such as students who are late joining class to students who are late in collecting assignments for various reasons. It means many improvements must be made to achieve the learning objectives in these online classes.

\section{REFERENCES}

Abidin, Z., \& Saputro, T. M. E. (2020). Google Classroom as a Mathematics learning space: Potentials and challenges. Journal of Physics: Conference Series, 1567(2), 1-6. https://doi.org/10.1088/17426596/1567/2/022094

Agung, A. S. S. N., Surtikanti, M. W., \& Op, C. A. Q. (2020). Students' Perception of Online Learning during COVID-19 Pandemic: A Case Study on the English Students of STKIP Pamane Talino. SOSHUM Jurnal 
Sosial Dan Humaniora [Journal of Social Sciences and Humanities], 10(2). 225-235. https://dx.doi.org/10.31940/soshum.v $10 \mathrm{i} 2.1316$

Afifi, G. M. H. (2011). E-learning as an alternative strategy for tourism higher education in Egypt. Quality Assurance in Education, 19(4), 357374.

https://doi.org/10.1108/09684881111 170078

Alim, N., Linda, W., Gunawan, F., \& Saad, M. S. M. (2019). The effectiveness of Google Classroom as an instructional media: A case of state Islamic institute of Kendari, Indonesia. Humanities and Social Sciences Reviews, $\quad 7(2), \quad 240-246$. https://doi.org/10.18510/hssr.2019.72 27

Ariantini, K. P., Suwastini, N. K. A., Adnyani, N. L. P. S., Dantes, G. R., \& Jayantini, I. G. A. S. R. (2021). Integrating social media into English language learning: How and to what benefits according to recent studies. NOBEL: Journal of Literature and Language Teaching, 12(1), 91-111. https://doi.org/https://doi.org/10.1564 2/NOBEL.2021.12.1.91-111

Atmojo, A. E. P., \& Nugroho, A. (2020). EFL Classes Must Go Online! Teaching Activities and Challenges during COVID-19 Pandemic in Indonesia. Register Journal, 13(1). 49-76.

https://doi.org/10.18326/rgt.v13i1.4976
Azhar, K. A., \& Iqbal, N. (2018). Effectiveness of Google Classroom: Teachers' perceptions. Prizren Social Science Journal, 2(2), 52-66. Retrieved from https://www.researchgate.net/journal/ Prizren-Social-Science-Journal-2616$387 \mathrm{X}$

Beaumont, K. (2018). Google Classroom: An online learning environment to support blended learning. Compass: Journal of Learning and Teaching, 11(2).

https://doi.org/10.21100/compass.v11 i2 2.837

Bhat, S., Raju, R., Bikramjit, A., \& D'souza, R. (2018). Leveraging elearning through Google Classroom: A usability study. Journal of Engineering Education Transformations, 31(3), 129-135. https://doi.org/10.16920/jeet/2018/v3 $1 \mathrm{i} 3 / 120781$

Dantes, G. R., Suarni, N. K., Dharsana, I. K., Dantes, N., Jayanta, I. N. L., Suwastini, N. K. A., \& Putra, G. J. A. (2019). Evaluation of e-learning as a learning agent. International Journal of Innovation and Learning, 25(4), 451-464.

https://doi.org/10.1504/IJIL.2019.099 989

Dwiyanti, K. E., \& Suwastini, N. K. A. (2021). Assessment for writing skills in online learning. Lingua Scientia, 28(1), 8-19. Retrieved from https://scholar.google.com/scholar?oi $=$ bibs\&cluster $=52243609581899106$ $44 \& b \operatorname{tnI}=1 \& \mathrm{hl}=\mathrm{en}$ 
Ersani, N. P. D., Suwastini, N. K. A., Padmadewi, N. N., \& Artini, L. P. (2021). Schemes of scaffolding in online education. Retorika: Jurnal Ilmu Bahasa, 7(1), 10-18. https://doi.org/https://doi.org/10.2222 5/jr.7.1.2941.10-18

Fauzan, F., \& Arifin, F. (2019). The effectiveness of Google Classroom media on the students' learning outcomes of Madrasah Ibtidaiyah Teacher Education Department. $A l$ Ibtida: Jurnal Pendidikan Guru MI, 6(2), 271. https://doi.org/10.24235/al.ibtida.snj. v6i2.5149

Guzman, M. J. De, Estira, K. L. A., Cabaluna, C. M., Espinosa, N. N., \& Ventayen, R. J. M. (2017). Usability evaluation of Google Classroom: Basis for the adaptation of GSuite elearning platform. The 5th International Conference on Studies in Business, Management, Education, And Law, 5(1), 47-51. Retrieved from

http://uruae.org/siteadmin/upload/DI RH0917218.pdf

Hassan, A. S. W., Ariffin, A., Ahmad, F., Sharberi, S. N. M., Nor Azizi, M. I., \& Zulkiflee, S. N. (2020). COVID-19 pandemic: Langkawi vocational college student challenge in using Google Classroom for Teaching and Learning (T\&L). International Journal of Advanced Trends in Computer Science and Engineering, 9(3), 3299-3307. https://doi.org/https://doi.org/10.3053 4/ijatcse/2020/127932020
Heggart, K. R., \& Yoo, J. (2018). Getting the most from Google Classroom: A pedagogical framework for tertiary educators. Australian Journal of Teacher Education, 43(3), 140-153. https://doi.org/10.14221/ajte.2018v43 n3.9

Iftakhar, S. (2016). Google Classroom: What works and how. Journal of Education and Social Sciences, 3(1), 12-18. Retrieved from http://jesoc.com/wpcontent/uploads/2016/03/KC3_35.pdf

Listiani, N. K. M., Suwastini, N. K. A., Dantes, G. R., Adnyani, N. L. P. S., \& Jayantini, I. G. A. S. R. (2021). YouTube as digital learning resources for teaching bilingual young learners. Proceedings of the 2nd International Conference on Technology and Educational Science (ICTES 2020), 540(ICTES 2020), 156-162. https://doi.org/https://dx.doi.org/10.2 991/assehr.k.210407.230

Megawati, F., \& Astutik, Y. (2019). EFL learning media: Perspective on elearning through Google Classroom. The 1st International Conference on Emerging Media and Social Science (ICEMSS), 1-6. Retrieved from http://dx.doi.org/10.4108/eai.7-122018.2281768

Miles, M. B., Huberman, A. M., \& Saldana, J. (2014). Qualitative data analysis: A methods sourcebook (3rd ed.; $\mathrm{H}$. Salmon, K. Perry, K. Koscielak, \& L. Barret, eds.). California: SAGE Publications. 
Minister of Education and Culture Indonesia. Pelaksanaan kebijakan pendidikan dalam masa darurat penyebaran Coronavirus Disease. , Pub. L. No. 4 (2020).

Ministry of Health Indonesia. Circular letter

No.HK.02.01/Menkes/199/2020. (2020).

Muslimah, A. (2018). A survey on the use of Google Classroom in English Language Education Department of Islamic University of Indonesia (Islamic University of Indonesia). Retrieved from https://dspace.uii.ac.id/bitstream/hand le/123456789/10932/A SURVEY ON THE USE OF GOOGLE CLASSROOM IN ENGLISH LANGUAGE EDUCATION DEPARTMENT OF ISLAMIC UNIVE.pdf?sequence $=13 \&$ is Allowe $\mathrm{d}=\mathrm{y}$

Nicholson, S. (2020). My Google Classroom: Training Guide (Kindle Edi). Retrieved from https://id1lib.org/dl/5464537/ad8dd8

Octaberlina, L. R., \& Muslimin, A. I. (2020). EFL students perspective towards online learning barriers and alternatives using moodle/google classroom during covid-19 pandemic. International Journal of Higher Education. $\quad 9 \quad$ (6), 1-9. https://doi.org/10.5430/ijhe.v9n6p1

Phoenix, M. (2020). Google Classroom: The 2020 ultimate user guide to master classroom (Kindle Edi). United States of America: Independently Published.
Puspawati, N. W. N., Suwastini, N. K. A., Hutapea, J. V., Dantes, G. R., \& Adnyani, N. L. P. S. (2021). Consumption and production of short film: Toward the conceptualization of multimodal language learning for developing 6Cs skills in the digital age. Journal of Physics: Conference Series, $1810(1)$. https://doi.org/10.1088/17426596/1810/1/012054

Puspitasari, P. I., Suwastini, N. K. A., Blangsinga, G. W. K. A. A., Dantes, G. R., \& Tuerah, I. J. C. (2021). Boomers' perception towards the implementation of online learning amidst Covid-19 outbreak. Proceedings of the 2nd International Conference on Technology and Educational Science (ICTES 2020), 540(Ictes 2020), 128-134. Atlantis Press.

Shaharanee, I. N. M., Jamil, J. M., \& Rodzi, S. S. M. (2016). Google Classroom as a tool for active learning. AIP Conference Proceedings 1761, 1-7. https://doi.org/https://doi.org/10.1063 /1.4960909

Slavin, R. E. (2017). Educational Psychology: Theory and Practice. In Psychological Bulletin (Vol. 25, Issue 7) (12th edition). https://doi.org/https://doi.org/10.1037 /h0074121

Sudarsana, I. K., Putra, I. B. M. A., Astawa, I. N. T., \& Yogantara, I. W. L. (2019). The use of Google Classroom in the learning process. Journal of Physics: Conference Series, 1175. https://doi.org/doi:10.1088/17426596/1175/1/012165 
Suhroh, F., \& Cahyono, B. Y. (2020). The perspective of Indonesian teachers on the Google Classroom usage in blended teaching. Jurnal Pendidikan, 5(10), 1495-1502. Retrieved from http://journal.um.ac.id/index.php/jptp p/article/view/14139

Sukmawati, \& Nensia. (2019). The role of Google Classroom in ELT. International Journal for Educational and Vocational Studies, 1(2), 142145 .

https://doi.org/https://doi.org/10.2910 3/ijevs.v1i2.1526

Suwastini, N. K. A., Rinawati, N. K. A., Jayantini, I. G. A. S. R., \& Dantes, G. R. (2021). Differentiated instruction across EFL classrooms: A conceptual review. TELL-US Journal, 7(1), 1441.

https://doi.org/http://dx.doi.org/10.22 202/tus.2021.v7i1.4719
Syakur, A., Sugirin, \& Widiarni. (2020). The effectiveness of English learning media through Google Classroom in higher education. Britain International of Linguistics, Arts and Education, 2(1), 483. https://doi.org/https://doi.org/10.3325 8/biolae.v2i1.218

Wang, H., \& Chen, C. W. (2019). Learning English from YouTubers: English L2 learners' self-regulated language learning on YouTube. Innovation in Language Learning and Teaching, 14(4), 1-14. https://doi.org/DOI: 10.1080/17501229.2019.1607356

Zakaria. (2021). Online learning in master educational administration program: Student's perception. IJEMI (International Journal of Educational Management and Innovation), 2(2), 240-248. https://doi.org/DOI: 10.12928/ijemi.v2i2.3749 